\title{
Task and Ego Goal Orientations across the Youth Sports Experience
}

\section{Orientace na úkolové cíle a ego cíle v rámci sportovních zkušeností mládeže}

\author{
Marc Lochbaum ${ }^{1,2}$, Ville Kallinen ${ }^{2,3}$, Niilo Konttinen ${ }^{2}$ \\ ${ }^{1}$ Texas Tech University, USA \\ ${ }^{2}$ Research Institute of Olympic Sports KIHU, Finland \\ ${ }^{3}$ University of Jyväskylä, Finland
}

\begin{abstract}
Since the late 1980s, Achievement Goal Theory (AGT) has flourished in the competitive sports research across all age groups. One central proposition is the undifferentiated conception of ability exist until approximately 12 years of age. Given the volume of AGT age-specific studies, quantitative analysis of available youth studies allows for examining whether the goal orientations (i.e., task and ego) scores change based on age (i.e., undifferentiated to the differentiated conception of ability). Hence, the purpose of this quantitative based review was to determine whether task and ego orientation values differ based on age. To achieve our objective, we conducted a meta-analysis with 16 studies meeting specified inclusion criteria one being the use of Perceptions of Success in Sport Questionnaire (POSQ) resulting in 19 samples. The total sample size was 5,679 with 14 studies with mean samples greater than 13-years of age and five equal to or under 12-years of age. The articles came from seven different countries with the USA and Norway accounting exactly half of all represented countries. There was a mix of sports played. Results demonstrated that ego orientation scores did not differ by age category. Initially, task orientation scores appeared to decrease after the age of 12. However, with one outlier removed, a lack of statistical significance $(p>.05)$ resulted. Theoretically, children move in youth to a differentiated conception of ability. It appears even though ability becomes not equal to effort in the minds of youth that self-reported goal orientation values as measured by the POSQ are stable. The implication of such results are many. One being children in competitive sports seemingly have a stable ego orientation score. A critical future research question concerns goal orientation differences among recreational youth sports participation as well as youth who discontinue both competitive and recreational sports participation. The role of goal orientations across these groupings and influence on participation rates is unknown.
\end{abstract}

\begin{abstract}
Abstrakt
Od konce osmdesátých let se teorie dosahování cílů (Achievement Goal Theory-AGT) hojně využívala v soutěžním sportovním výzkumu ve všech věkových kategoriích. Jedna z ústředních tezí je nediferencované pojetí schopností až do 12 let věku. Vzhledem $k$ objemu věkově specifických studií umožňuje kvantitativní analýza dostupných studií o mládeži prozkoumat, zda se cílová orientace (tj. na cíl a ego) měni podle věku (tj. od nediferencované $k$ diferencované koncepci schopnosti). Cílem tohoto kvantitativního přezkumu bylo tedy zjistit, zda se orientace na úkol a ego liší podle věku. $K$ dosažení našeho cíle jsme provedli metaanalýzu se 16 studiemi, které splnily stanovená kritéria pro zařazení, přičemž jedním z nich bylo využití výsledků dotazníku Vnímání úspěchu ve sportu (POSQ) s výstupem 19 vzorků. Celková velikost vzorku byla 5679 se 14 studiemi s průměrnými vzorky vyššími než 13 let a pěti s dětmi ve věku 12 let nebo mladšími než 12 let. Články pocházejí ze sedmi různých zemí, přičemž USA a Norsko činily přesně polovinu všech zastoupených zemí. Zastoupeny byly různé sporty. Výsledky ukázaly, že skóre orientace na ego se podle věkové kategorie nelišilo. Z počátku se zdálo, že po dosažení věku 12 let se skóre orientace na cíl snízilo. Nicméně s odstraněním jednoho okrajového výsledku se ukázala nedostatečná statistická významnost ( $p>0.05$ ). Teoreticky se u dětí vyvíjejí v mládí diferencované
\end{abstract}


schopnosti. Zdá se, že i když v myslích mládeže schopnosti neodpovídají úsilí, jsou hodnoty sebehodnocení na cílovou orientaci měřené pomocí POSQ stabilní. Důsledků těchto výsledků je mnoho. Dítě zapojené do závodního sportu má podle všeho stabilní orientaci na ego. Kritická budoucí výzkumná otázka se týká rozdílu orientace na cíl mezi rekreačnímu účastníky mládežnických sportů a těmi, kteří se prestanou účastnit závodního nebo rekreačního sportu. Úloha cílové orientace v těchto skupinách a vliv na míru účasti není známa.

Keywords: motivation, competitive sports, meta-analysis, Achievement Goal Theory

Klíčová slova: motivace, výkonnostní sporty, metaanalýza, teorie dosažení cíle

\section{INTRODUCTION}

Since the late 1980s, Achievement Goal Theory (AGT) has flourished in the competitive sports across all age groups (Lochbaum, Kazak Çetinkalp, Graham, Wright, \& Zazo, 2016; Lochbaum, Zazo, Kazak Çetinkalp, Graham, Wright, \& Konttinen, 2016). Sports psychology researchers followed Nicholls' (1989) conceptualization. Nicholls' built his framework upon the following two central assumptions: individuals operate rationally, and the adopted achievement goal guides future achievement decisions and behaviors.

The number one goal of action in Nicholls' framework is the demonstration of competence. Thus, perceptions of ability are central in achievement goal research. Nicholls theorized that the two conceptions of ability are differentiated and undifferentiated. These two conceptions of ability define the two orthogonal and implicit achievement goal orientations as task and ego. Nicholls theorized these two implicit orientations determine achievement beliefs and behaviors. Also, Nicholls hypothesized the orientations to reflect ways in which humans define success and failure and ways in which one infers demonstrated competence.

The task orientation operates when personal mastery, improvement, and achievement of higher ability motivate action. With this orientation, athletes define success and failure subjectively by their self-referenced perceptions of performance. An ego orientation operates when the desire to demonstrate normative competence such as beating an opponent, demonstrating superior ability, and showing off motivates behaviors. Athletes judge success and failure by comparisons with the performance of other competitors.

One central proposition is the undifferentiated conception of ability (i.e., effort and ability are equal in a child's mind) exist until approximately 12 years of age. Whether this essential proposition affects task and ego orientation scores is unknown. The AGT literature implies a task goal is desirable while an ego goal is undesirable. Do competitive sports increase ego orientation scores and decrease task orientation scores? Given the volume of AGT age-specific studies, quantitative analysis of available youth studies allows for examining whether the goal orientations (i.e., task and ego) scores change based on age (i.e., undifferentiated to the differentiated conception of ability). Hence, the purpose of this quantitative based review was to determine whether task and ego orientation values differ based on age in a competitive sports environment. 


\section{METHOD}

\section{Search Strategy}

We based the literature search mainly on Lochbaum, Kazak Çetinkalp, and colleagues' (2016) work. Lochbaum, Kazak Çetinkalp, and colleagues (2016) provided a table indicating which studies included youth participants. We retrieved all of those studies. Also, systematic and comprehensive search occurred for studies in 2016 (up until December 31, 2016). As with Lochbaum and his colleagues, EBSCO was the chosen the electronic database for the search with individual databases specific to sports (SPORTDiscus), psychology (PsycINFO), and education (ERIC). The basis of the keyword combinations to locate published studies were the following terms in conjunction with youth sports: goal orientations and sport, goal orientations and competitive sport, task orientation and sport, task orientation and competitive sport, ego orientation and sport, and ego orientation and competitive sport.

\section{Eligibility Criteria}

Articles retained for our particular purpose were clear. Papers must be in peer-reviewed journals, and not theses, book chapters, and or conference proceedings up to December 31, 2016. The data must be original and include sample size, goal orientation means, standard deviations (or standard errors), and mean age of the sample. The participants must be youth participating in a competitive sports context. Last, the authors must have used the POSQ on a 1 to 5 scale to assess the goal orientations. Articles excluded did not meet all of the above criteria. We considered, as did Lochbaum, Kazak Çetinkalp, and colleagues, articles written in any language.

\section{DATA ANALYSIS PROCEDURES}

Study characteristics. Given our purpose was mainly to test whether the ego goal differed by age category, we coded studies as mean age less than 13 years of age and 13 years of age and older (to 18 years old). We did not anticipate enough studies based on reading Lochbaum and colleagues' (2016a) POSQ table that we would include any other characteristic (e.g., sports type, country of origin).

Quantitative analyses. We used the Comprehensive Meta-Analysis (CMA) version-3 software (version 3.3.070, Biostat, Inc. November 20, 2014). To test our age category hypothesis, we utilized the estimate of means option for continuous mean data within CMA and imputed means, standard deviations, and sample sizes. We created an age category moderator variable and tested the difference between the two goal orientations by age with the group mix-methods analysis option. For the goal orientation estimated means, we examined funnel plots to determine if the entered studies were dispersed equally on either side of the overall estimated means. Symmetry theoretically represents that the reviewed studies captured the essence of all relevant studies. To assess symmetry, we utilized Duval and Tweedie's (2000) trim and fill analysis.

Statistical assumptions of error. Two primary models exist to determine statistical assumptions of error. Thus, one must choose one. The fixed effects model assumes that all of the gathered studies share a common effect and differences are a result of within-study error or sampling error. The random effects model assumes both within study error and between-study variation. Even with an eventual small number of studies relative to Lochbaum and colleagues (2016a), a great variety of seemed most likely. Thus, we chose the random effects model. 


\section{RESULTS}

\section{Sample summary}

Tables 1 provides specifics concerning the study authors, year, country, age category, sample size, sex makeup of sample, the competitive sport, the questionnaire, and data each study provided. We included 16 studies from 1998 to 2016 in the review that contributed 19 samples. The studies came from seven different countries. USA (31.25\%) and Norway (18.75\%) accounting exactly half of all represented countries. There was a mix of sports such as judo, basketball, soccer, and handball. The total sample size was 5,679 with 14 data points with mean samples greater than 13 -years of age and 5 with youth samples of 12-years of age or less.

Tab. 1: Characteristics for included studies and mean (standard deviation) for task and ego data

\begin{tabular}{|l|c|c|c|c|c|c|}
\hline Study & Year & Country & Age & N & Sex & Sport \\
\hline Nerland and Sæther & 2016 & Norway & $>13$ & 140 & M & Soccer \\
\hline Rottensteiner et al. & 2015 & Finland & $>13$ & 1962 & M & Mixed \\
\hline Lochbaum and Podlog & 2014 & USA & $>13$ & 112 & M & Football \\
\hline Heng et al. & 2011 & Malaysia & $>13$ & 80 & B & Mixed \\
\hline Sage and Kavussanu & 2007 & UK & $>13$ & 365 & B & Soccer \\
\hline D'Arripe-Longueville et al. & 2006 & France & $12<$ & 163 & M & Judo \\
\hline & & France & $>13$ & 158 & M & Judo \\
\hline Cecchini et al. & 2004 & Spain & $>13$ & 96 & B & Mixed \\
\hline Rascle and Coulomb & 2003 & France & $>13$ & 109 & M & Handball \\
\hline Lemyre et al. & 2002 & Norway & $>13$ & 511 & M & Soccer \\
\hline Cervello and Santa-Rosa & 2001 & Spain & $>13$ & 323 & B & Mixed \\
\hline Gernigon and le Bars & 2000 & USA & $12<$ & 38 & B & Aikido \\
\hline & & USA & $12<$ & 42 & B & Judo \\
\hline Kavussanu and Harnisch & 2000 & USA & $12<$ & 907 & B & Mixed \\
\hline Ommundsen and Pedersen & 1999 & Norway & $>13$ & 136 & F & Not stated \\
\hline Ryska and Yin & 1999 & USA & $12<$ & 103 & B & Soccer \\
\hline Rascle et al. & 1998 & France & $>13$ & 80 & M & Handball \\
\hline & & France & $>13$ & 80 & M & Handball \\
\hline Treasure and Roberts & 1998 & USA & $>13$ & 274 & F & Basketball \\
\hline
\end{tabular}

Note. USA = United States of America; UK = United Kingdom; $M=$ male only sample; $F=$ female only sample; $B=$ mixed gender sample.

Ego orientation results. Across all 19 samples, the ego goal estimated random effects mean value was 3.35 (95\% lower limit 3.22, 95\% upper limit 3.49). The trim and fill analysis suggested the samples are representative of the population (see Figure 1). No 'fills' appeared required, thus these data appear confidently representing the entire population of youths in competitive sports. A non-significant, $\mathrm{Q}(1)=.092, \mathrm{p}=.76$, group mixed effects analysis resulted. The estimated mean for the younger group was 3.31 (95\% lower limit 2.99, 95\% upper limit 3.62) and for the older youth group was 3.36 (95\% lower limit 3.20, 95\% upper limit 3.52). Hence, the results were unsupportive regarding the traditional hypothesis concerning the ego goal orientation increasing after age 12-years of age.

Task orientation results. Across all 19 samples, the task goal estimated random effects mean value was 4.26 (95\% lower limit 4.14, 95\% upper limit 4.38). The trim and fill analysis suggested 
the samples needed an adjustment to be representative based mainly on one or two studies with obviously low task values (i.e., Heng et al., 2011; Ommundsen \& Petersen, 1999).

Six 'fills' appeared required that slightly adjusted the estimate mean value down to 4.14 (95\% lower limit 4.03, 95\% upper limit 4.26). A significant, $\mathrm{Q}(1)=4.63, \mathrm{p}=.031$ ) group mixed effects analysis resulted. The estimated mean for the younger group was 4.42 (95\% lower limit 4.30 , 95\% upper limit 4.53) and for the older youth group was 4.21 (95\% lower limit 4.05, 95\% upper limit 4.36). The results suggest staying in competitive sport marginally lowers the task orientation scores.

Removal of Ommundsen and Petersen (1999) barely changed the results. The trim and fill analysis required five 'fills' instead of six (see Figure 2). The adjusted mean values increased slightly to 4.26 (95\% lower limit 4.18, 95\% upper limit 4.33). Even with this slight increase, the group mixed effects analysis changed, $\mathrm{Q}(1)=2.30, \mathrm{p}=.129$. The estimated mean for the younger group was still 4.42 (95\% lower limit 4.30, 95\% upper limit 4.53$)$ and increased for the older youth group to 4.30 (95\% lower limit $4.20,95 \%$ upper limit 4.40 ). The results suggest staying in competitive sport does not significantly $(\mathrm{p}>.05)$ lower the task orientation scores.

\section{Funnel Plot of Standard Error by Mean}

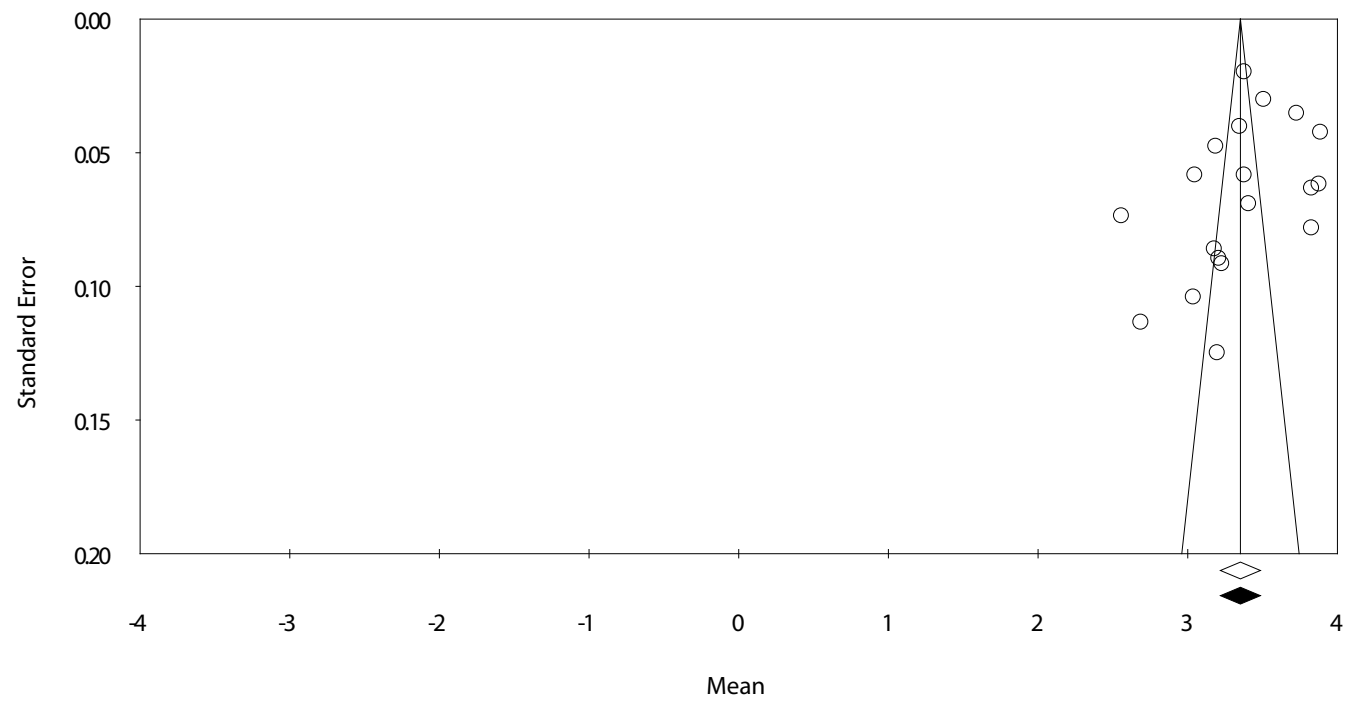

Fig. 1: Funnel plot for ego orientation samples 
Funnel Plot of Standard Error by Mean

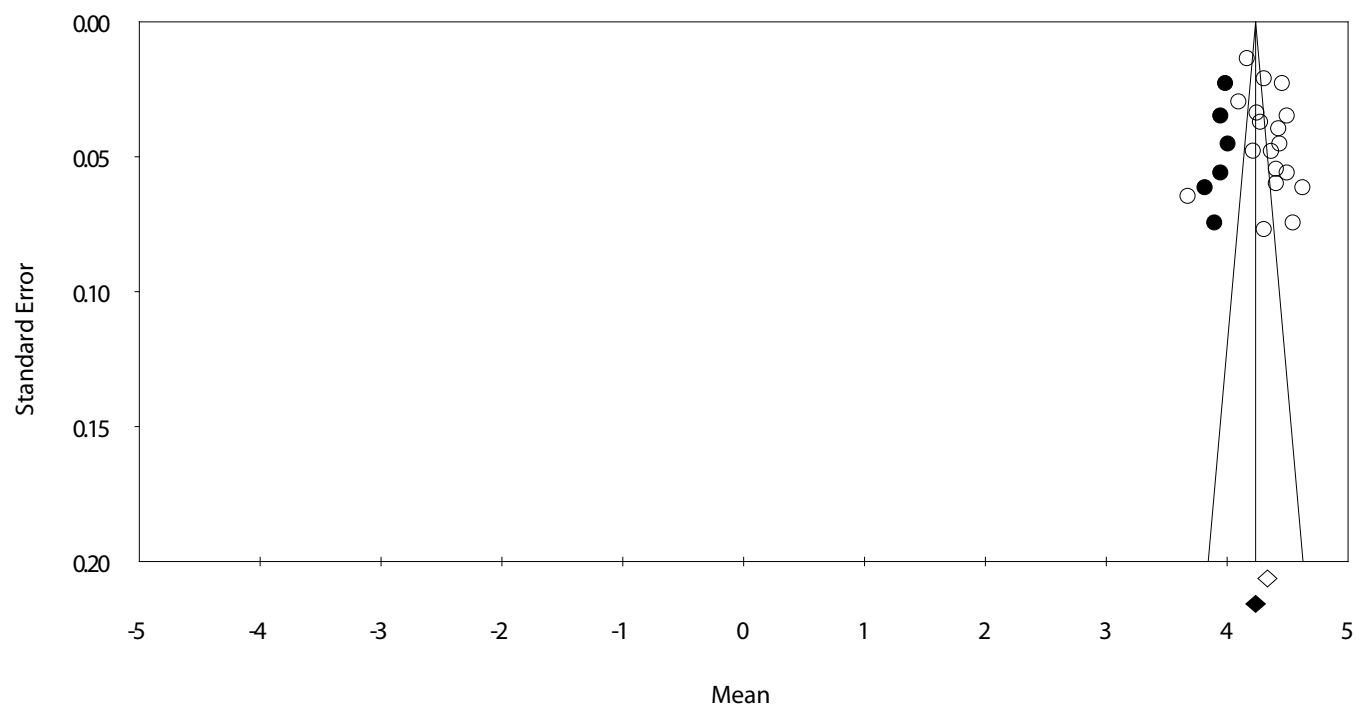

Fig. 2: Funnel plot for task orientation samples with outlier removed

\section{DISCUSSION}

Theoretically, children move in youth to a differentiated conception of ability from the undifferentiated view of ability. Conceptually, knowing that one's ability is not equal to the effort one gives is one reason for participation discontinuation in any achievement context with low ability perceptions. It is not enjoyable to realize that one's efforts may not compensate a lack of natural ability for one's chosen sport. Whether goal orientation scores change along with the change in ability conceptions is a vital research question when examining youth sports participation.

Much controversy surrounds AGT and the consequences of competitive sports participation. Researchers over decades have implicated that the ego orientation associates with all that are detrimental in sports. Meta-analytic research does not support such strong assertions (Lochbaum, Zazo, et al., 2016). Nevertheless, if an ego orientation score increases and a task orientation score decreases as one passes from an undifferentiated to the differentiated conception of ability, one might especially with low ability perceptions discontinue sports participation.

At the Research Institute of Olympic Sports KIHU, we extensively examine youth sports participation motivations centered on AGT as measured by the POSQ. Therefore, this quantitative review is essential to our research and shaping of competitive sports clubs in Finland. Based on the results, it appears even though ability becomes not equal to the exerted effort one gives after the age of 12 years that self-reported goal orientation values as measured by the POSQ are stable.

The implication of such results is many. One being children in competitive sports seemingly have a stable ego orientation score. Whether the mean values from youth in competitive sports represent all kids regardless of their sports participation background is unknown. A critical future research question concerns goal orientation differences among recreational youth sports participants and competitive sports participants as well as youth who discontinue both competitive and recreational sports participation. Do competitive sports detrimentally change youths' goal orientations and influence participation rates? The role of goal orientations across these type of youth 
participation groupings is unknown. We center our work at the Research Institute of Olympic Sports KIHU on this question in the hopes of retaining youths in sports clubs.

\section{References}

Cecchini, J. A., González, C., Carmona, Á. M., \& Contreras, O. (2004). Relaciones entre clima motivacional, la orientación de meta, la motivación intrínseca, la auto-confianza, la ansiedad y el estado de ánimo en jóvenes deportistas. [Relationships among motivational climate, achievement goals, intrinsic motivation, self-confidence, anxiety, and mood in young sport players. In Spanish.] Psicothema, 16(1), 104-109.

Cervelló, E. M., \& Santos-Rosa, F. J. (2001). Motivation in sport: An achievement goal perspective in young Spanish recreational athletes. Perceptual and Motor Skills, 92(2), 527-534.

D'Arripe-Longueville, F., Pantaléon, N., \& Smith, A. L. (2006). Personal and situational predictors of sportspersonship in young athletes. International Journal of Sport Psychology, 37(1), 38-57.

Gernigon, C., \& le Bars, H. (2000). Achievement goals in aikido and judo: A comparative study among beginner and experienced practitioners. Journal of Applied Sport Psychology, 12(2), 168-179.

Heng, S. Y., Fauzee, M., Omar, S., \& Soh, K. G. (2011). The relationship between imagery and perception of success among male and female high school athletes. Asian Journal of Physical Education \& Recreation, 17(2), 83-92.

Kavussanu, M., \& Harnisch, D. L. (2000). Self-esteem in children: Do goal orientations matter?. British Journal of Educational Psychology, 70(2), 229-242.

Lemyre, P. N., Hall, H. K., \& Roberts, G. C. (2007). A social cognitive approach to burnout in elite athletes. Scandinavian Journal of Medicine \& Science in Sports, 18(2), 221-234.

Lochbaum, M., Kazak Çetinkalp, Z., Graham, K., Wright, T., \& Zazo, R. (2016). Task and ego goal orientations in competitive sport: A quantitative review of the literature from 1989 to 2016. Kinesiology, 48, 3-29.

Lochbaum, M. R., \& Podlog, L. W. (2014). Mental toughness and pre-game mental states in adolescent football players: The mediating role of achievement goals. Scientific Theory Journal, 118, 262-266.

Lochbaum, M., Zazo, R., Kazak Çetinkalp, Z., Graham, K., Wright, T., \& Konttinen, N. (2016). A meta-analytic review of achievement goal orientation correlates in competitive sport: A follow-up to Lochbaum et al. (2016). Kinesiology, 48, 159-173.

Nerland, E., \& Sæther, S. A. (2016). Norwegian football academy players-players self-assessed competence, perfectionism, goal orientations and motivational climate. Sport Mont, 14(2), 7-11.

Nicholls, J. G. (1989). The competitive ethos and democratic education. Cambridge, MA: Harvard University Press.

Ommundsen, Y., \& Pedersen, B. H. (1999). The role of achievement goal orientations and perceived ability upon somatic and cognitive indices of sport competition trait anxiety: A study of young athletes. Scandinavian Journal of Medicine \& Science in Sports, 9(6), 333-343.

Rascle, O., \& Coulomb, G. (2003). Aggression in youth handball: Relationships between goal orientations and induced motivational context. Social Behavior \& Personality, 31(1), 21-34.

Rottensteiner, C., Tolvanen, A., Laakso, L., \& Konttinen, N. (2015). Youth athletes' motivation, perceived competence, and persistence in organized team sports. Journal of Sport Behavior, 38(4), 1-18.

Ryska, T. A., \& Yin, Z. (1999). Dispositional and situational goal orientations as discriminators among recreational and competitive league athletes. The Journal of Social Psychology, 139(3), 335-342.

Sage, L., \& Kavussanu, M. (2007). Multiple goal orientations as predictors of moral behavior in youth soccer. Sport Psychologist, 21(4), 417-437.

Treasure, D. C., \& Roberts, G. C. (1994). Cognitive and affective concomitants of task and ego goal orientations during the middle school years. Journal of Sport \& Exercise Psychology, 16(1), 15-28.

\section{Corresponding author:}

Marc Lochbaum, Ph.D.

Email:marc.lochbaum@ttu.edu 